ISSN: 2146-3042

DOI: $10.25095 /$ mufad.872153

\title{
Uluslararası Muhasebe ve Finansal Raporlama Standartları Araştırmaları Üzerine Bir İnceleme*
}

İbrahim Apak**

\section{ÖZET}

Bu çalıșmanın amacl, finansal piyasalara şeffaflı, hesap verebilirlik ve verimlilik getirmesi amaciyla gelişstirilen Uluslararası Finansal Raporlama Standartları (UFRS) araşstırmalarının incelenmesidir. Bu kapsamda çeşitli ülkelerde gerçekleştirilen araştırmalar UFRS'ye yönelik algl, geçiş öncesi-sonrası ve UFRS'nin ekonomik sonuçları olmak üzere üç kategori altında incelenmiştir. Çalışmada UFRS'ye yönelik birincil ve ikincil veri kaynaklarında elde edilen verilerle gerçekleştirilen araştırmalarda elde edilen bulgular karşılaş̧ırmalı olarak yorumlanmaktadır. Araştırmaların bulgularına göre UFRS ile elde edilen sonuçlar ülkeden ülkeye farklllı göstermektedir. Araşttrmalarda UFRS öncesinde tespit edilen (olumlu-olumsuz) öngörülerin büyük ölçüde gerçekleştiği ve UFRS'nin karşılaşıtırlabilirlik dışında diğer getirilerinin bazı ülkeler için sınırlı düzeyde kaldı̆̆ bulgulanmıştır. Bazı ülkeler içinse bulgular UFRS'nin faydadan çok zarara neden olduğu yönündedir. UFRS özellikle denetim ve denetim dışı ücretlerde artı̧sa neden olarak işletmelerde maliyetlere yol açmıştır. Bu maliyetlerin gelecekte artarak ilerleyeceği düşünülmektedir. UFRS'nin fayda/maliyet dengesinin işletme aleyhine bozulduğunu gösteren araştırmalar lehine olduğunu gösteren araştırmalardan daha fazladır.
\end{abstract}

Anahtar Kelimeler: Muhasebe; Finansal Raporlama; UFRS.

JEL Siniflandirması: M40, M41,M49

\section{A Review on International Accounting and Financial Reporting Standards Researches}

\section{ABSTRACT}

This study aims to examine researches that realized on International Financial Reporting Standards (IFRS) that were developed to bring transparency, accountability, and efficiency to financial markets. In this context, researches conducted in various countries are examined under three categories: perception towards IFRS, pre-post transition and economic consequences of IFRS. In the study, the findings obtained from the researches conducted with the data obtained from primary and secondary data sources for IFRS are discussed comparatively. According to the findings of the researches, IFRS results differ from country to country. In the researches that IFRS (positive-negative) perceptions are determined before the IFRS, results show that the benefits of the IFRS remain limited for some countries except for comparability. Beyond that, for some countries, IFRS causes more harm than good. IFRS causes costs to businesses, especially by causing an increase in audit and non-audit fees. It is thought that these costs will increase in the future. Most of the researches show that the benefit/cost balance of IFRS is not in favor of the company.

Keywords: Accounting; Financial Reporting; IFRS.

Jel Classification: M40, M41,M49.

\footnotetext{
* Makale Gönderim Tarihi: 01.02.2021, Makale Kabul Tarihi: 13.04.2021, Makale Türü: Nitel Araştırma

** Dr. Öğr. Üyesi, Aksaray Üniversitesi, Sosyal Bilimler Meslek Yüksekokulu, Muhasebe ve Vergi Uygulamaları Bölümü, apakibrahim@gmail.com, ORCID: 0000-0002-5404-0361.
} 


\section{GíRiş}

Dünya genelinde uluslararası sermaye piyasalarının şeffaflık ve karşılaştırılabilirliğin artırılması konusunda yol açtı̆ı baskı muhasebe süreçleri ve raporlama konusunda bir takım ortak standartların kullanılmasını gerektirmiştir (Mikova, 2014: 2571). Bu kapsamda geliştirilen UFRS başta Avrupa Birliği olmak üzere 2018 yılında 144 ülkede (veya bölgede) kullanılır hale gelmiştir (IASB, 2018: 2). 1 Ocak 2005 tarihinde Avrupa Birliği ülkelerinde halka açık işletmelerde UFRS uygulama zorunluluğu ${ }^{1} 1$ Ocak 2021 itibariyle 16 yılı geride bırakmıştır.

UFRS'nin küresel ölçekte ilgi çekmesi ve kabul görmesi aynı zamanda dikkatleri üzerine çekmiş ve tartışmaları da beraberinde getirmiştir (Atwood vd., 2011: 104). UFRS'nin kullanımı her geçen gün artarken literatürde UFRS'nin getirisine yönelik bulgular içeren sınırlı sayıdaki araştırmada UFRS'nin getirisine yönelik farklı bulgular yer almaktadır.

$\mathrm{Bu}$ çalışmada UFRS üzerine gerçekleştirilmiş araştırmalar üç kategori altında ele alınmaktadır. Birincisini UFRS uygulaması öncesinde yapılan UFRS'nin getirileri, olas1 faydaları ve ekonomik sonuçlarına yönelik araştırmalar oluşturmaktadır. İkincisi UFRS sonrasında gerçekleştirilen ve UFRS'ye geçiş öncesi ve sonrasının incelendiği araştırmalardır. Üçüncüsü ise UFRS'nin yol açtığı güçlükler ve ekonomik sonuçlarını inceleyen araştırmalardır. Çalışmada üç kategori altında sınıflandırılan UFRS araştırmalarında elde edilen bulgular karşılaştırmalı olarak ele alınmakta ve yorumlanmaktadır. $\mathrm{Bu}$ sayede UFRS'nin öncesinde gerek UFRS kurucuları ve gerekse de kullanıcılarının beklediği yararlar ve ekonomik sonuçlarının literatürdeki araştırmalar ışı̆̆ında bir değerlendirmesi gerçekleştirilmektedir.

\section{MUHASEBE VE FINANSAL RAPORLAMA STANDARTLARINA GEÇIŞ}

UFRS şüphesiz muhasebe tarihi içerisindeki önemli yasal düzenlemelerden birisi olmuştur. Düzenleyiciler UFRS'nin finansal tabloların karşılaştırılabilirliğini, kurumsal şeffaflığ ve finansal raporlama kalitesini artırması ile yatırımcılara ve işletmelere fayda sağlamasını beklemektedirler (Daske vd., 2008: 1086). Uluslararası Muhasebe Standartları Kurulu $^{2}$ na (IASB) göre UFRS ile küresel ölçekte kabul edilebilir muhasebe standartları seti sağlanarak uluslararası finansal raporlama farklılıklarının azaltılması amaçlanmaktadır (Jones ve Finley, 2011: 22).

UFRS'yi oluşturan IASB misyonunu, “dünya genelindeki finans piyasalarına şeffafllk, hesap verebilirlik ve verimlilik getiren UFRS Standartları geliștirmektir. Çalışmamız, küresel ekonomide güveni, büyümeyi ve uzun vadeli finansal istikrarı teşvik ederek kamu yararına hizmet etmektedir" şeklinde belirtmektedir. Ayrıca UFRS'nin dünya ekonomisine katkısını şeffaflık, hesap verebilirlik ve verimlilik vurgusuyla aşağıdaki şekilde açıklamaktadır (IASB, 2018: 7):

\footnotetext{
${ }^{1}$ İlgili karar için bakınız: Regulation (EC) No. 1606/2002 of the European Parliament and of the Council of 19 July 2002

${ }^{2}$ International Accounting Standards Board
} 
- UFRS Standartları, uluslararası karşılaştırılabilirliği ve finansal bilginin kalitesini artırarak şeffaflı getirir, yatırımclların ve diğer piyasa katılımcllarının bilgiye dayalı ekonomik kararlar almasını sağlar.

- $\quad$ UFRS Standartları, sermaye sağlayıcıları ile paraların emanet ettikleri kişiler arasindaki bilgi uçurumunu azaltarak hesap verebilirliği güçlendirir. Standartlarımız, yönetimi sorumlu tutmak için gereken bilgileri sağlar. Küresel olarak karşılaştırılabilir bilgi kaynağı olarak, UFRS Standartları aynı zamanda dünyanın her yerindeki düzenleyiciler için hayati önem taşımaktadir.

- UFRS Standartları, yattrmcıların dünya çapındaki firsatları ve riskleri belirlemelerine yardımcı olarak ekonomik verimliliğe katkıda bulunur ve böylece sermaye dağılımını iyileştirir. İşletmeler için, tek ve güvenilir bir muhasebe dilinin kullanılması sermaye maliyetini düşürür ve uluslararası raporlama maliyetlerini düşürür.

UFRS'nin bu varsayılan beklenti ve faydaları hakkındaki bulgular genellikle çelişkili ve tartışmalıdır (Dayanandan vd., 2016: 297). Çünkü UFRS gelişmiş ve gelişmekte olan ülkeler için farklı sonuçlar verebilmektedir (Tyrrall vd., 2007: 8; Moscariello, Skerratt ve Pizzo, 2004: 64) ve UFRS'nin bir ülke veya bölgede beklenen yararları sağlayabilmesi için UFRS tek başına yeterli değildir. Ülkedeki hukuki yapı ve geleneği, kurumsal yönetim düzeyi, hissedar korumaya yönelik düzenlemeler gibi hâlihazırda mevcut yapı UFRS uygulaması ve sonuçlarını etkileyebilmektedir (Karampinis ve Hevas, 2011: 305). Örneğin Avrupa'da kazanç yönetimi işletmeler arasında artı̧̧ göstermiş olsa da ülkeler arasında tek tip bir yapıya dönüşmemiştir (Ugrin vd., 2017: 140). Ayrıca Doan vd. (2020) yönetim faktörlerinin ve sosyo-ekonomik ve kültürel koşulların UFRS uygulanabilirliği üzerinde belirsiz bir etkiye sahip olduğunu da ortaya koymaktadır.

UFRS'ye yönelik araştırmalar çoğunlukla UFRS'ye geçiş biçimleri olan zorunlu ve gönüllü (mandatory, voluntary) geçiş biçimleri üzerine odaklanmaktadır (Daske vd., 2008: 1086). UFRS'ye geçiş biçimi ve elde edilecek sonuçlara ilişkin bir genelleme yapılacak olursa; UFRS'ye zorunlu geçişte, yürürlükte olan yerel muhasebe standartları ${ }^{3}$, UFRS'den düşük kalitedeyse zorunlu UFRS'nin fayda sağlaması beklentisi yerinde olacaktır. Öte yandan, hâlihazırda kullanılmakta olan yerel muhasebe standartları UFRS'den yüksek kalitedeyse, zorunlu UFRS geçişi muhasebe ve finansal raporlama kalitesinde düşüşe yol açması beklenebilir (Ahmed vd., 2013: 1344).

Clements vd., (2010) UFRS'ye geçiş kararında kültürel çeşitlilik ve ülke büyüklüğünü ele aldıkları araştırmalarında kültürel çeşitlilik ve ülke büyüklüğünün UFRS'ye geçiş kararında etkili olduğunu bulgulamışlardır. Ayrıca büyük ülkelerin UFRS'ye geçme olasılı̆ıının küçük ülkelere göre daha düşük olduğunu belirtmektedirler. Bunun nedenini ise büyük ülkelerin çoğunlukla iyi düzenlenmiş finansal muhasebe ve raporlama standartları geliştirmiş oldukları ve uluslararası standartlara geçerek değişimin yol açacağı maliyete katlanma konusunda isteksiz davranabilecekleri şeklinde açıklamışlardır. (Clements vd., 2010: 124).

UFRS'ye geçişte bir diğer konu ise pek çok ülkenin kendi yerel muhasebe standartlarını oluşturmada yeterli düzeyde olmamalarıdır. Kaya ve Koch (2015) 128 ülke

\footnotetext{
${ }^{3}$ Çalışma içerisinde yerel muhasebe standartları ifadesi, ilgili ülke (veya bölge) için yürürlükte olan genel kabul görmüş muhasebe ilkeleri, kuralları ve prensipleri anlamında kullanılmaktadır.
} 
üzerinde yaptıkları araştırmalarında kendi yerel standartlarını oluşturabilecek kapasiteden yoksun olan ülkelerin UFRS'ye geçtiklerini bulgulamışlardır. Bu durum ülkelerin kendi standartlarını oluşturmak yerine UFRS'yi benimsemeleri noktasında önemli bir faktördür.

\section{UFRS ARAŞTIRMALARI}

UFRS'ye yönelik belirli ülke ve/veya birden çok ülkede UFRS’ye geçiş öncesinde algılanan ve sonrasında gerçekleşen fayda, getiri, maliyet araştırmalarına bu kısımda üç kategori altında yer verilmektedir. Bunlar, UFRS'ye geçiş öncesinde UFRS'nin algılanan faydaları-sakıncalarına yönelik araştırmalar, UFRS'ye geçiş öncesi-sonrası (pre-post) araştırmaları ve UFRS'nin işletmelerde yol açttğı güçlükler ve ekonomik sonuçları üzerine araştırmalardır. Çeşitli ülkelerde birincil ve ikincil veri kullanılarak UFRS'ye yönelik gerçekleştirilmiş araştırmalar incelenerek elde edilen bulgular karşılaştırmalı olarak yorumlanmıştır.

Çalışma kapsamında incelenen UFRS araştırmalarına, ScienceDirect, JSTOR, EBSCO ve Emerald Insight üzerinden UFRS'ye geçiş (transition to IFRS), UFRS ve maliyet (cost of IFRS), UFRS öncesi-sonrası (Pre-Post IFRS), UFRS'nin algılanan etkileri (perceived effects of IFRS), UFRS'nin etkileri (impact of UFRS) ve UFRS'nin sonuçları (results of IFRS) anahtar kelimeleriyle aramalar gerçekleştirilerek ulaşıılmıştır. İlgili aramalar sırasında yayın yılı aralığı 2000-2020 yılları ile sınırlandırılmıştır. Arama sonuçlarında ulaşılan makaleler üç kategoriye ayrılarak incelenmiştir.

\subsection{UFRS'ye Geçiş Öncesinde Algılanan Fayda-Sakıncalar}

UFRS'ye geçiş öncesinde UFRS'nin işletmeler ve diğer çeşitli çevrelerce algılanan faydaları-sakıncaları üzerine gerçekleştirilen araştırmalara Tablo 1'de yer verilmektedir.

Tablo 1. UFRS'ye Geçiş Öncesinde Algılanan Fayda-Sakıncalar

\begin{tabular}{|c|c|c|c|}
\hline Araştırma(lar) & Ülke(ler) & $\begin{array}{l}\text { Araştırma Kapsamı ve } \\
\text { Kullanılan Veri }\end{array}$ & Araştırma Bulguları ve Sonuçları \\
\hline $\begin{array}{l}\text { (Jermakowicz, } \\
\text { 2004) }\end{array}$ & Belçika & $\begin{array}{l}\text { UFRS'ye geçiş ile birlikte } \\
\text { UFRS'nin işletmelerin örgüt } \\
\text { yapısı, muhasebe ve finans } \\
\text { stratejileri üzerinde ortaya } \\
\text { çıkacak etkileri. UFRS'nin } \\
\text { yararları ve ortaya çıkardığı } \\
\text { güçlükler, UFRS'nin algılanan } \\
\text { kalitesinin analizi. } 2003 \\
\text { yılında halka açı işletmelerle } \\
\text { (n=20) anket ve mülakatlar } \\
\text { aracıllğı̆ıla veri toplama }\end{array}$ & $\begin{array}{l}\text { İşletmeler UFRS'nin içsel ve dışsal } \\
\text { finansal raporlama dizaynııı kökten } \\
\text { değiştireceğini belirtmektedir. UFRS'nin } \\
\text { karşılaştırlabilirlik, şeffaflık ve gerçeğe } \\
\text { uygun değer noktasında katkı } \\
\text { sağlayacağını ifade etmektedirler. Öte } \\
\text { yandan işletmeler UFRS'nin } \\
\text { uygulamasının bilinmediğini ve } \\
\text { anlaşılamadığını vurgulamaktadır. } \\
\text { Gerçeğe uygun değerin raporlanan } \\
\text { kalemlerde önemli ölçüde oynaklığa yol } \\
\text { açacağı ve UFRS'nin kompleks yapısının } \\
\text { işletmelere maliyet yükü getireceği } \\
\text { düşünülmektedir. Uygulama rehberlerinin } \\
\text { eksikliği, vergi odaklı muhasebe sistemi } \\
\text { ile uyumsuzluk UFRS uygulamaları } \\
\text { açısından karşlaşıllacak güçlükler olarak } \\
\text { belirtilse de muhasebe sisteminde } \\
\text { meydana gelecek değişim } \\
\text { karşıllaştırılabilirlik ve büyüme noktasında }\end{array}$ \\
\hline
\end{tabular}




\begin{tabular}{|c|c|c|c|}
\hline & & & $\begin{array}{l}\text { işletmelere olumlu etki sağlayacağı } \\
\text { beklenmektedir. }\end{array}$ \\
\hline $\begin{array}{l}\text { (Jermakowicz } \\
\text { ve Gornik- } \\
\text { Tomaszewski, } \\
\text { 2006) }\end{array}$ & $\begin{array}{l}\text { Avusturya, } \\
\text { Belçika, } \\
\text { Danimarka, } \\
\text { Fransa, } \\
\text { Almanya, } \\
\text { İlanda, } \\
\text { Hollanda, } \\
\text { Birleşik } \\
\text { Krallik }\end{array}$ & $\begin{array}{l}\text { Avrupa Birliği’nde UFRS’ye } \\
\text { geçiş öncesi görüşler. } 2004 \\
\text { yılında Avrupa Birliği’nde yer } \\
\text { alan, halka açık işletmelerden } \\
(n=112) \text { anket verisi. }\end{array}$ & $\begin{array}{l}\text { Katılımcıların büyük çoğunluğu UFRS'yi } \\
\text { konsolidasyon amacından daha fazlası için } \\
\text { benimsediklerini ifade etmektedirler. } \\
\text { Ayrıca katılımcılar UFRS sürecinin } \\
\text { maliyetli, kompleks, külfetli olduğunu ve } \\
\text { UFRS ile sermaye maliyetlerinin } \\
\text { düşmesini beklemediklerini } \\
\text { belirtmektedirler. Katılımcılar UFRS ile } \\
\text { birlikte finansal sonuçlarda oynaklığın } \\
\text { artış göstereceğini, UFRS'nin kompleks } \\
\text { yapısı, uygulama rehberinin eksikliği ve } \\
\text { standart yorumların temel güçlükler } \\
\text { olduğunu ifade etmişlerdir. Son olarak } \\
\text { katılımcıların büyük çoğunluğu Avrupa } \\
\text { Birliği’nin yasal düzenlemesi olmasa } \\
\text { UFRS'yi işletmelerinde } \\
\text { uygulamayacaklarını belirtmişlerdir. }\end{array}$ \\
\hline $\begin{array}{l}\text { (Jones ve } \\
\text { Higgins, 2006) }\end{array}$ & Avustralya & $\begin{array}{l}\text { UFRS'ye zorunlu geçişe } \\
\text { işletmelerin hazırlılı olup } \\
\text { olmadıkları, UFRS'nin olası } \\
\text { etkileri/sonuçları ve } \\
\text { fayda/maliyet beklentisi. } 2003 \\
\text { y1lında borsada işlem gören } \\
\text { Top 200'de yer alan } \\
\text { işletmelerin (n=60) üst } \\
\text { yöneticileri ile telefonda anket } \\
\text { uygulaması }\end{array}$ & $\begin{array}{l}\text { Bulgulara göre büyük ölçekli işletmeler } \\
\text { UFRS'ye geçişe hazır olma ve beklenen } \\
\text { sonuçları noktasında küçük ölçekli } \\
\text { işletmelere göre daha kapsamlı bilgiye } \\
\text { sahip. UFRS ile ortaya çıkacak iş yükü ile } \\
\text { işletme büyüklüğü arasında korelasyon } \\
\text { tespit edilmiş. Araştırma bulgularına göre } \\
\text { katılımcılar UFRS'ye geçişin işletmelere } \\
\text { maliyet yükü getireceğini öngörmekte } \\
\text { ancak UFRS'nin sağlayacağı faydanın } \\
\text { belirsiz olduğunu düşünmektedir. }\end{array}$ \\
\hline $\begin{array}{l}\text { (Nurunnabi, } \\
\text { 2018) }\end{array}$ & $\begin{array}{l}\text { Suudi } \\
\text { Arabistan }\end{array}$ & $\begin{array}{l}\text { UFRS öncesinde UFRS'ye } \\
\text { geçişin getireceği maliyet ve } \\
\text { sağlayacağı fayda } \\
\text { incelenmektedir. Bu kapsamda } \\
\text { borsada işlem göre şirketlerde } \\
\text { muhasebeciler, Big Four'dan } \\
\text { denetçiler, yerel muhasebe } \\
\text { firmaları ve üniversitelerden } \\
\text { akademisyenlerle mülakatlar } \\
\text { gerçekleştirilmiştir. }\end{array}$ & $\begin{array}{l}\text { Bulgulara göre UFRS'nin getireceği } \\
\text { faydalar, yol açacağı maliyetlere göre } \\
\text { daha yüksek olacaktır. Öte yandan, } \\
\text { kalifiye muhasebeci eksikliği, Big Four } \\
\text { muhasebe firmalarına önemli düzeyde } \\
\text { bağımlılık, üniversite eğitiminde ve } \\
\text { araştırmalarında UFRS'nin eksikliği, } \\
\text { UFRS'nin etkinliğinin önündeki engeller } \\
\text { olarak tanımlanmaktadır. }\end{array}$ \\
\hline
\end{tabular}

Tablo 1'de yer alan araştırmalar incelendiğinde UFRS öncesinde gerçekleştirilen araştırmalarda UFRS'nin işletmelere karşılaştırılabilirlik, şeffaflık, konsolidasyon ve gerçeğe uygun değer açısından katkı sağlayacağı beklentisi yer almaktadır. Benzer şekilde UFRS ile işletmelere konsolidasyon dişında büyüme, düşük maliyetli sermayeye erişim gibi faydalar sağlayacağı öngörülmektedir. Fayda/maliyet açısından bakıldığında ise faydanın yüksek olacağı ve maliyetin yüksek olacağı yönünde farklı görüşler bulunmaktadır.

UFRS'nin neden olacağı sakıncalara ilişkin algılar ise gerçeğe uygun değer ve finansal sonuçlarda oynaklığın olumsuz sonuçlara neden olacağı, UFRS'nin işletmelere maliyet yükü getireceği, UFRS'nin kompleks yapısı ve uygulama rehberlerinin eksikliğinin güçlüklere yol açacağı şeklindedir. Ayrıca araştırmalarda büyük ölçekli işletmelerin işlem hacmi nedeniyle;

\footnotetext{
${ }^{4}$ Dört büyük denetim firması
} 
küçük ölçekli işletmelerinse rehber eksikliği ve kaynakların sınırlılı̆ı nedeniyle dezavantajlı olacağı belirtilmektedir. UFRS ile başta Big Four olmak üzere denetim firmalarına bağımlılık artışı, kalifiye muhasebe elemanı eksikliği ve standartlara ilişkin yorumlamaların güçlükler ortaya çıkaracağı ve tüm bunların karşılığında UFRS'nin getireceği faydanın belirsiz olduğuna ilişkin görüşler UFRS öncesinde yapılan araştırmalarda belirlenen görüşlerdendir.

\subsection{UFRS’ye Geçiș Öncesi-Sonrası (Pre-Post) Araștırmaları}

UFRS'ye zorunlu veya gönüllü geçiş gerçekleştirmiş ülkelerde gerçekleştirilen ve UFRS öncesi ve sonrasına ait veri setleri üzerinden yapılan analizler sonrasında UFRS'nin farklı açılardan fayda veya zararlarına ilişkin bulgular içeren araştırmalara Tablo 2'de yer verilmektedir.

Tablo 2. UFRS'ye Geçiş Öncesi-Sonrası Araştırmaları

\begin{tabular}{|c|c|c|c|}
\hline Araştırma(lar) & Ülke(ler) & $\begin{array}{l}\text { Araştırma Kapsamı ve } \\
\text { Kullanılan Veri }\end{array}$ & Araştırma Bulguları ve Sonuçları \\
\hline (Mikova, 2014) & $\begin{array}{l}\text { Fransa, } \\
\text { Birleșik } \\
\text { Krallık }\end{array}$ & $\begin{array}{l}\text { Kazanç yönetimi üzerinden } \\
\text { UFRS’nin raporlama kalitesi } \\
\text { üzerine etkisi. 2000-2013 } \\
\text { y1lları arasında } 526 \text { şirket } \\
\text { (6822 firma yıl1 gözlemi) }\end{array}$ & $\begin{array}{l}\text { UFRS muhasebe kalitesi üzerinde düşük- } \\
\text { orta düzeyde pozitif etkiye sahip olduğu } \\
\text { sonucuna ulaşlmıştır. }\end{array}$ \\
\hline $\begin{array}{l}\text { (Shah vd., } \\
\text { 2013) }\end{array}$ & $\begin{array}{l}\text { Birleşik } \\
\text { Krallık }\end{array}$ & $\begin{array}{l}\text { UFRS öncesi ve sonrası Ar-Ge } \\
\text { harcamalarının değer ilişkisi } \\
\text { (value relevance). 2001-2011 } \\
\text { yılları arasında borsada işlem } \\
\text { gören } 1.415 \text { şirket (15,565 } \\
\text { firma yılı gözlemi) }\end{array}$ & $\begin{array}{l}\text { Gider yazılan Ar-Ge harcamalarında } \\
\text { UFRS öncesi ve sonrasında değer } \\
\text { ilişkisinde farklılık olmadığı ve } \\
\text { aktifleştirilen Ar-Ge harcamalarında değer } \\
\text { ilişkisi (UFRS öncesine göre) UFRS } \\
\text { sonrasında düşüş gösterdiği } \\
\text { bulgulanmıştır. }\end{array}$ \\
\hline $\begin{array}{l}\text { (Jones ve } \\
\text { Finley, 2011) }\end{array}$ & $\begin{array}{l}\text { Avustralya, } \\
\text { Birleşik } \\
\text { Krallık, } \\
\text { Almanya, } \\
\text { Avusturya, } \\
\text { Fransa, } \\
\text { İspanya, } \\
\text { Irlanda, } \\
\text { Macaristan, } \\
\text { Yunanistan, } \\
\text { İveç, } \\
\text { Portekiz, } \\
\text { Belçika, Çek } \\
\text { Cumhuriyeti, } \\
\text { İtalya, } \\
\text { Danimarka, } \\
\text { Norveç, } \\
\text { Polonya, } \\
\text { Finlandiya, } \\
\text { Lüksemburg }\end{array}$ & $\begin{array}{l}\text { Avrupa Birliği ve } \\
\text { Avustralya'da zorunlu } \\
\text { UFRS'ye geçişin finansal } \\
\text { raporlama farklılıklarını } \\
\text { azaltıp azaltmadığı } \\
\text { incelenmektedir. 1994-2004 ve } \\
2006 \text { yıllarına ilişkin Thomson } \\
\text { Reuter's One Banker ve } \\
\text { Worldscope üzerinden veri. }\end{array}$ & $\begin{array}{l}\text { UFRS sonrasında Avrupa Birliği ve } \\
\text { Avustralya’da faaliyet gösteren } \\
\text { işletmelerin ( } 81,560 \text { firma yılı gözlemi) } \\
\text { finansal raporlarında farkl1lıkların } \\
\text { azalması noktasında istatistiki olarak } \\
\text { anlamlı bazı düşüşlerin olduğu } \\
\text { bulgulanmışıtır. }\end{array}$ \\
\hline $\begin{array}{l}\text { (Dayanandan } \\
\text { vd., 2016) }\end{array}$ & 35 Ülke & $\begin{array}{l}\text { UFRS'ye geçiş sonrasında } \\
\text { Avrupa'da ve dünyada çeşitli } \\
\text { ülkelerde finansal raporlama } \\
\text { kalitesinin artıp artmadığını } \\
\text { incelenmesi. 2002-2008 }\end{array}$ & $\begin{array}{l}\text { Bulgulara göre UFRS finansal raporlama } \\
\text { kalitesini artırmıştır. UFRS'ye geçiş } \\
\text { yüksek düzeyde finansal bildirim olan } \\
\text { ülkelerde kazanç yönetimini düşürdüğg̈ } \\
\text { yönünde bulgular sağlamaktadır. }\end{array}$ \\
\hline
\end{tabular}




\begin{tabular}{|c|c|c|c|}
\hline & & $\begin{array}{l}\text { arasında işletmelere ait } \\
(\mathrm{n}=3.030) \text { OSIRIS ve Dünya } \\
\text { Bankası üzerinden veri. }\end{array}$ & \\
\hline $\begin{array}{l}\text { (Ahmed vd., } \\
\text { 2013) }\end{array}$ & $\begin{array}{l}\text { Yunanistan, } \\
\text { İtalya, } \\
\text { Filipinler, } \\
\text { Portekiz, } \\
\text { Güney Afrika, } \\
\text { İspanya, } \\
\text { Avustralya, } \\
\text { Avusturya, } \\
\text { Belçika, } \\
\text { Danimarka, } \\
\text { Finlandiya, } \\
\text { Fransa, } \\
\text { Almanya, } \\
\text { Hong Kong, } \\
\text { İrlanda, } \\
\text { Hollanda, } \\
\text { Norveç, İsveç, } \\
\text { İsviçre, } \\
\text { Birleşik } \\
\text { Krallik, } \\
\text { Arjantin, } \\
\text { Brezilya, Şili, } \\
\text { Hindistan, } \\
\text { İsrail, Kore } \\
\text { Cumhuriyeti, } \\
\text { Malezya, } \\
\text { Meksika, } \\
\text { Pakistan, } \\
\text { Tayvan, } \\
\text { Kanada, } \\
\text { Japonya, Yeni } \\
\text { Zelanda, } \\
\text { Birleşik } \\
\text { Devletler }\end{array}$ & $\begin{array}{l}\text { UFRS’ye geçişin muhasebe } \\
\text { kalitesi üzerine etkisi. 2002- } \\
2007 \text { y1lları arasında } 20 \\
\text { ülkeden } 3.262 \text { firma (16.310 } \\
\text { firma y1lı gözlemi). } \\
\text { COMPUSTAT üzerinden veri. }\end{array}$ & $\begin{array}{l}\text { Kazanç yönetimi, kârın istikrarlı hale } \\
\text { getirilmesi (income smoothing) ve } \\
\text { manipülatif raporlama (reporting } \\
\text { aggressiveness) üzerinden UFRS’ye } \\
\text { zorunlu geçişin muhasebe kalitesi üzerine } \\
\text { etkisi ele alınmaktadır. Zorunlu UFRS’ye } \\
\text { geçiş sonrasında muhasebe kalitesinde } \\
\text { düşüş meydana geldiği bulgusuna } \\
\text { ulaşılmıştır. }\end{array}$ \\
\hline $\begin{array}{l}\text { (Atwood vd., } \\
\text { 2011) }\end{array}$ & $\begin{array}{l}\text { Avustralya, } \\
\text { Avusturya, } \\
\text { Belçika, } \\
\text { Brezilya, } \\
\text { Danimarka, } \\
\text { Finlandiya, } \\
\text { Fransa, } \\
\text { Almanya, } \\
\text { Yunanistan, } \\
\text { Hong Kong, } \\
\text { Endonezya, } \\
\text { İtalya, Kore, } \\
\text { Malezya, } \\
\text { Meksika, } \\
\text { Hollanda, } \\
\text { Norveç, } \\
\text { Filipinler, } \\
\text { Singapur, } \\
\text { Güney Afrika, } \\
\text { İspanya, İsveç, }\end{array}$ & $\begin{array}{l}\text { UFRS ve US GAAP } \\
\text { kıyaslamas1. 2002-2008 } \\
\text { arasında } 33 \text { ülkeden } 58.832 \\
\text { firma y1lı gözlemi. } \\
\text { COMPUSTAT üzerinden veri. }\end{array}$ & $\begin{array}{l}\text { Raporlanmış kazanç ve gelecek nakit } \\
\text { akışları üzerinden Birleşik Devletler } \\
\text { Genel Kabul Görmüş Muhasebe } \\
\text { Prensipleri (US GAAP), UFRS ve } \\
\text { domestik DAS muhasebe standartları } \\
\text { kıyaslaması ele alınmaktadır. UFRS } \\
\text { altında raporlanan pozitif kazancın } \\
\text { sürekliliği US GAAP altında } \\
\text { raporlanandan farklı değil. US GAAP } \\
\text { altında hazırlanan raporlardaki kazançlar } \\
\text { UFRS'ye göre gelecek nakit akışlarıyla } \\
\text { daha ilişkili olduğu bulgusuna ulaşılmıştır. }\end{array}$ \\
\hline
\end{tabular}




\begin{tabular}{|c|c|c|c|}
\hline & $\begin{array}{l}\text { İsviçre, } \\
\text { Tayland, } \\
\text { Birleşik } \\
\text { Krallık, } \\
\text { Kanada, Şili, } \\
\text { Hindistan, } \\
\text { Japonya, Yeni } \\
\text { Zelanda, } \\
\text { Tayvan, } \\
\text { Birleşik } \\
\text { Devletler } \\
\end{array}$ & & \\
\hline (Trimble, 2018) & 46 Ülke & $\begin{array}{l}\text { UFRS'ye zorunlu geçişin kâr } \\
\text { dağıtımları üzerinden } \\
\text { muhasebe kalitesine etkisi. } \\
\text { UFRS'ye geçiş yapmış } 46 \\
\text { ülkeden } 5.691 \text { firma verisi. }\end{array}$ & $\begin{array}{l}\text { Bulgulara göre, UFRS'ye geçişle birlikte } \\
\text { muhasebe kalitesinde artış meydana } \\
\text { gelmiştir. Bu bulgu hem gelişmekte olan } \\
\text { ülkeler için hem de gelişmiş ülkeler için } \\
\text { geçerli olduğu ifade edilmiştir. }\end{array}$ \\
\hline $\begin{array}{l}\text { (Downes vd., } \\
\text { 2018) }\end{array}$ & $\begin{array}{l}\text { Avusturya, } \\
\text { Finlandiya, } \\
\text { Fransa, } \\
\text { Almanya, } \\
\text { Yunanistan, } \\
\text { İtalya, } \\
\text { Hollanda, } \\
\text { İspanya, İsveç, } \\
\text { Birleşik } \\
\text { Krallık }\end{array}$ & $\begin{array}{l}\text { Finansal raporlamada meydana } \\
\text { gelen değişim ve halka açık } \\
\text { işletmelerin pazar payı. 2000- } \\
2010 \text { yılları arasında Avrupa } \\
\text { Birliği’ndeki ülkelerinde yer } \\
\text { alan işletmelerin verileri. } \\
\text { Bureau Van Dijk's Orbis } \\
\text { veritabanı üzerinden. }\end{array}$ & $\begin{array}{l}\text { Bulgulara göre UFRS ile gelen finansal } \\
\text { raporlama düzenlemesi halka açık } \\
\text { işletmelerin pazar payı ve ürün } \\
\text { piyasasındaki rekabet ile ilişki vardır. } \\
\text { Zorunlu UFRS uygulayıcılarının, } \\
\text { uygulamayanlara göre daha yüksek } \\
\text { finansal raporlama kalitesini elde ederek } \\
\text { düşük maliyetli finansmana ulaşma } \\
\text { imkânını artırabildiği için firmanın pazar } \\
\text { payını artırmasını sağlamaktadır. }\end{array}$ \\
\hline $\begin{array}{l}\text { (Zor ve Korga, } \\
2020)\end{array}$ & Türkiye & $\begin{array}{l}\text { UFRS'ye geçiş sonrasında } \\
\text { kazanç yönetimi uygulamaları } \\
\text { incelenmektedir. } \\
2000-2008 \text { yılları arasında } \\
\text { borsaya kayıtlı imalat } \\
\text { sektöründeki işletmelerin } \\
\text { (n=37) finansal verileri ve } \\
\text { Bloomberg veri tabanı } \\
\text { üzerinden. }\end{array}$ & $\begin{array}{l}\text { Bulgulara göre UFRS sonrasında } \\
\text { işletmelerin kazanç yönetimi uygulamaları } \\
\text { azalmıştır. }\end{array}$ \\
\hline $\begin{array}{l}\text { (Tsalavoutas } \\
\text { vd., 2012) }\end{array}$ & Yunanistan & $\begin{array}{l}\text { UFRS'ye zorunlu geçişin öz } \\
\text { sermayenin defter değeri ve } \\
\text { net gelir değer ilişkisi. 2001- } \\
2008 \text { arasında halka açık } \\
\text { işletmelerden UFRS öncesi ve } \\
\text { sonrasına ait veri DataStream } \\
\text { üzerinden ve finansal rapor } \\
\text { dipnotlarından. }\end{array}$ & $\begin{array}{l}\text { Bulgulara göre UFRS öncesi ve sonrası } \\
\text { karşılaştırıldığında öz sermaye defter } \\
\text { değeri ve net gelir arasında önemli bir } \\
\text { değişim yoktur. Bu bulgu ile UFRS'nin } \\
\text { muhasebe kalitesinde meydana getireceği } \\
\text { artış öngörülerini desteklememektedir. }\end{array}$ \\
\hline $\begin{array}{l}\text { (Kousenidis } \\
\text { vd., 2010) }\end{array}$ & Yunanistan & $\begin{array}{l}\text { UFRS öncesi ve sonrası } \\
\text { dönemde muhasebe bilgisinin } \\
\text { değer ilişkisi. 2003-2006 } \\
\text { yılları arasında borsada işlem } \\
\text { gören işletmelerden }(\mathrm{n}=159) \\
\text { Profile veri tabanı üzerinden } \\
\text { veri. }\end{array}$ & $\begin{array}{l}\text { Bulgulara göre UFRS hisse senedi } \\
\text { fiyatları için öz sermaye defter } \\
\text { değerlerinin artan bilgi içeriğini azalttı̆̆ını } \\
\text { göstermektedir. Başka bir ifadeyle UFRS } \\
\text { mevcut bilgiye yapılacak ilave bilgileri } \\
\text { azaltarak bilgi kullanıcılarına hisse senedi } \\
\text { fiyatları için öz sermaye defter değeri } \\
\text { konusunda daha az bilgi sunulmasına } \\
\text { neden olmuştur. UFRS gerçek değer } \\
\text { prensibiyle defter değerleri üzerinde } \\
\text { önemli değişimlere neden olurken } \\
\text { kazançlar üzerinde etkili olmamıştır. } \\
\text { UFRS sonrası dönemde kazançlar }\end{array}$ \\
\hline
\end{tabular}




\begin{tabular}{|c|c|c|c|}
\hline & & & $\begin{array}{l}\text { üzerinden ilave bilgiler sunulmasını } \\
\text { sağlamıştır. }\end{array}$ \\
\hline $\begin{array}{l}\text { (Beneish vd., } \\
\text { 2015) }\end{array}$ & 47 Ülke & $\begin{array}{l}\text { Makroekonomik veriler } \\
\text { üzerinden zorunlu UFRS'ye } \\
\text { geçişin ülkelerin yabancı borç } \\
\text { ve sermaye piyasası } \\
\text { yatırımlarını artırıp artırmadığı } \\
\text { incelenmektedir. 2004-2007 } \\
\text { yılları arasında UFRS'ye geçiş } \\
\text { yapmış ve yapmamış } \\
\text { ülkelerden veriler. }\end{array}$ & $\begin{array}{l}\text { Bulgulara göre UFRS'ye geçiş yabancı } \\
\text { borç piyasası akışlarında sermaye piyasası } \\
\text { yatırım akışlarına göre daha büyük etki } \\
\text { etmiştir. UFRS'ye zorunlu geçişin yararı } \\
\text { finansal tablo karşılaştırılabilirliğinden } \\
\text { çok raporlama kalitesindeki artış olarak } \\
\text { belirtilmiştir. }\end{array}$ \\
\hline $\begin{array}{l}\text { (Sellami ve } \\
\text { Slimi, 2016) }\end{array}$ & Güney Afrika & $\begin{array}{l}\text { UFRS'ye zorunlu geçişin } \\
\text { kazanç yönetimi üzerinden } \\
\text { muhasebe kalitesine katkısının } \\
\text { incelenmesi. } \\
2002-2012 \text { arasında } 46 \text { Güney } \\
\text { Afrika halka açı işletme } \\
\text { verisi (276 firma yllı gözlemi). }\end{array}$ & $\begin{array}{l}\text { Bulgulara göre UFRS'ye geçiş düşük } \\
\text { kazanç yönetimini ve dolayısıyla } \\
\text { muhasebe bilgisinde ve finansal raporlama } \\
\text { kalitesinde artış sağlamıştır. }\end{array}$ \\
\hline $\begin{array}{l}\text { (Jeanjean ve } \\
\text { Stolowy, 2008) }\end{array}$ & $\begin{array}{l}\text { Avustralya, } \\
\text { Fransa, } \\
\text { Birleşik } \\
\text { Krallık }\end{array}$ & $\begin{array}{l}\text { UFRS'ye zorunlu geçişin } \\
\text { kazanç yönetimi üzerinde } \\
\text { etkileri ele alınmaktadır. 2003- } \\
2006 \text { yılları arasında UFRS'yi } \\
\text { ilk defa uygulayan işletme } \\
\text { (n=1146) verileri. }\end{array}$ & $\begin{array}{l}\text { Kazanç yönetiminin yaygınlığının } \\
\text { UFRS'nin uygulanmaya başlamasında } \\
\text { sonra azalmadığını ve hatta Fransa'da } \\
\text { arttığı bulgulanmıştır. Araştırmada } \\
\text { standartların işletmeler arasında ortak bir } \\
\text { iş dili oluşturmak için yeterli olmadığı ve } \\
\text { yönetim teşviklerinin ve ulusal kurumsal } \\
\text { faktörlerin finansal raporlama } \\
\text { özelliklerinin belirlenmesinde önemli bir } \\
\text { rol oynadığını vurgulanmaktadır. }\end{array}$ \\
\hline (Erin vd., 2017) & Nijerya & $\begin{array}{l}\text { UFRS öncesi ve sonrası } \\
\text { dönemde muhasebe verilerinin } \\
\text { fiyat ve getiri değerleri } \\
\text { üzerinden değer ilişkisi. 2008- } \\
2015 \text { yılları arasına ilişkin } \\
\text { işletme }(n=52) \text { verisi. }\end{array}$ & $\begin{array}{l}\text { Bulgulara göre fiyat ve getiri regresyon } \\
\text { modelleri üzerinden UFRS sonrasında, } \\
\text { öncesine göre artış tespit edilmiştir. } \\
\text { Ayrıca UFRS kazanç, nakit akış, defter } \\
\text { değeri ve net gelir gibi muhasebe } \\
\text { verilerinde değer ilişkisini geliştirmiştir. }\end{array}$ \\
\hline $\begin{array}{l}\text { (Humeedat, } \\
\text { 2019) }\end{array}$ & Ürdün & $\begin{array}{l}\text { UFRS öncesi ve sonrası } \\
\text { dönemde muhasebe } \\
\text { muhafazakârlığında } \\
\text { (ihtiyatlılık, accounting } \\
\text { conservatism) değişim. 2000- } \\
2017 \text { yılları arasında borsada } \\
\text { işlem gören banka ( } \mathrm{n}=13 \text { ) } \\
\text { verisi. }\end{array}$ & $\begin{array}{l}\text { Bulgulara göre ilgili süreç içerisinde } \\
\text { UFRS'ye geçiş sonrasında muhasebe } \\
\text { muhafazakârlığında artış tespit edilmiştir. } \\
\text { Ayrıca muhasebe kazançlarındaki } \\
\text { muhasebe muhafazakârlığında UFRS } \\
\text { sonrasında önemli farklılık tespit } \\
\text { edilmiştir. }\end{array}$ \\
\hline $\begin{array}{l}\text { (Alhadi vd., } \\
\text { 2018) }\end{array}$ & Malezya & $\begin{array}{l}\text { UFRS'ye geçiş sonrasında } \\
\text { kazanç kalitesinde artış } \\
\text { meydana gelip gelmediğinin } \\
\text { incelenmesi. 2007-2016 } \\
\text { arasında işletme ( } \mathrm{n}=196) \text { verisi } \\
\text { (1960 firma yılı gözlemi) } \\
\end{array}$ & $\begin{array}{l}\text { Bulgulara göre UFRS'ye geçiş sonrasında } \\
\text { kazanç kalitesi önemli ölçüde artmıştır. }\end{array}$ \\
\hline (Lin vd., 2012) & Almanya & $\begin{array}{l}\text { U.S. GAAP'tan UFRS'ye geçiş } \\
\text { ile muhasebe kalitesinde } \\
\text { değişim olup olmadığı } \\
\text { incelenmektedir. 2000-2010 } \\
\text { yılları arasında U.S. GAAP'tan } \\
\text { UFRS'ye geçen } 63 \text { Alman } \\
\text { yüksek teknoloji işletmesi } \\
\text { verisi (582 firma yılı gözlemi). }\end{array}$ & $\begin{array}{l}\text { Bulgulara göre U.S. GAAP'ın uygulaması } \\
\text { UFRS'ye daha yüksek muhasebe kalitesi } \\
\text { sunmaktadır ve U.S. GAAP'tan UFRS'ye } \\
\text { geçiş muhasebe kalitesini düşürmüştür. }\end{array}$ \\
\hline
\end{tabular}




\begin{tabular}{|c|c|c|c|}
\hline & & Worldscope üzerinden. & \\
\hline $\begin{array}{l}\text { (Chalmers vd., } \\
\text { 2011) }\end{array}$ & Avustralya & $\begin{array}{l}\text { UFRS'ye geçişin muhasebe } \\
\text { bilgilerinin değer ilişkisini } \\
\text { artırıp artırmadığı } \\
\text { incelenmektedir. 1990-2008 } \\
\text { yılları arasında borsada işlem } \\
\text { göre işletmelerin verileri } \\
\text { (20,025 firma yılı gözlemi). }\end{array}$ & $\begin{array}{l}\text { Bulgulara göre kazançların UFRS } \\
\text { sonrasında değer ilişkisi daha yüksek hale } \\
\text { gelmiştir. Ayrıca kazançlar UFRS } \\
\text { sonrasında daha kalıcı (sürekli) hale } \\
\text { gelmiştir. Güçlü yatırımcı koruması, } \\
\text { yüksek kalitede finansal raporlama ve } \\
\text { uygulama olan ülkelerde UFRS'ye geçiş } \\
\text { muhasebe bilgisi ve piyasa değeri } \\
\text { arasındaki ilişkiyi etkilediği } \\
\text { bulgulanmıștır. }\end{array}$ \\
\hline (Neel, 2017) & 23 Ülke & $\begin{array}{l}\text { UFRS'ye zorunlu geçişin } \\
\text { işletmeler }(\mathrm{n}=1861) \text { için } \\
\text { ekonomik sonuçları, muhasebe } \\
\text { karşılaştırılabilirliği ve } \\
\text { raporlama kalitesini } \\
\text { incelenmektedir. }\end{array}$ & $\begin{array}{l}\text { Bulgulara göre UFRS'ye geçiş sonrasında } \\
\text { karşılaştırılabilirlik artışı olan işletmelerde } \\
\text { Tobin's Q, likidite, tahmin doğruluğu ve } \\
\text { tahmin tutarlılığında büyük artışlar tespit } \\
\text { edilmiştir. Diğer yandan muhasebe } \\
\text { kalitesinde kısıtlı kalmıştır. Ülkeler arası } \\
\text { muhasebe karşılaştırılabilirliğindeki } \\
\text { gelişmeler UFRS'ye geçişte önemli rol } \\
\text { oynadığı ifade edilmiştir. }\end{array}$ \\
\hline $\begin{array}{l}\text { (Kaya vd., } \\
\text { 2015) }\end{array}$ & Türkiye & $\begin{array}{l}\text { Tekstil sektöründe faaliyet } \\
\text { gösteren işletmelerin öncesi ve } \\
\text { sonrasında verimlilik } \\
\text { değerlerinin karşılaştırılması } \\
\text { ele alınmaktadır. 1998-2011 } \\
\text { yılları arasında borsada işlem } \\
\text { gören işletmelerin ( } \mathrm{n}=13 \text { ) } \\
\text { verileri üzerinden. }\end{array}$ & $\begin{array}{l}\text { Bulgulara göre işletmelerin UFRS öncesi } \\
\text { ve sonrası dönem için hesaplanan } \\
\text { verimlilikleri arasında istatistiki olarak } \\
\text { anlamlı bir farklılık olmadığı sonucuna } \\
\text { varılmıştır. }\end{array}$ \\
\hline $\begin{array}{l}\text { (Fuad vd., } \\
\text { 2019) }\end{array}$ & Endonezya & $\begin{array}{l}\text { UFRS'ye geçiş sonrasında } \\
\text { muhasebe kalitesinde artış } \\
\text { olup olmadığı incelenmektedir. } \\
\text { 2008-2014 yılları arasında } \\
\text { işletme verisi ( } 3.861 \text { firma yılı } \\
\text { gözlemi). }\end{array}$ & $\begin{array}{l}\text { Bulgulara göre UFRS sonrasında } \\
\text { muhasebe kalitesinde artış olduğuna dair } \\
\text { kesin kanıtlar bulunmamaktadır. }\end{array}$ \\
\hline (Nechita, 2018) & Romanya & $\begin{array}{l}\text { UFRS'ye geçiş sonrasında } \\
\text { finansal raporlama kalitesinde } \\
\text { artış olup olmadığı } \\
\text { incelenmektedir. Borsada } \\
\text { işlem gören işletmelerin } \\
(\mathrm{n}=16) \text { verisi. }\end{array}$ & $\begin{array}{l}\text { Bulgulara göre UFRS sonrasında } \\
\text { tahakkuk kalitesinde artış ve kazanç } \\
\text { yönetiminde düşüş tespit edilmiştir. Bu } \\
\text { durum UFRS'nin finansal raporlama } \\
\text { kalitesini artırdığı yönünde } \\
\text { yorumlanabilir. }\end{array}$ \\
\hline $\begin{array}{l}\text { (Kim O. , } \\
\text { 2016) }\end{array}$ & Rusya & $\begin{array}{l}\text { UFRS'ye geçişin halka açık } \\
\text { işletmelerde finansal } \\
\text { raporlama kaliteleri üzerine } \\
\text { etkisi incelenmektedir. 2009- } \\
2021 \text { yılları arasında borsada } \\
\text { işlem gören işletme ( } \mathrm{n}=119) \\
\text { verisi. }\end{array}$ & $\begin{array}{l}\text { Bulgulara göre UFRS'ye geçen işletmeler } \\
\text { raporlama kalitesinde önemli gelişmeler } \\
\text { yaşamıştır. }\end{array}$ \\
\hline $\begin{array}{l}\text { (Oral ve Bekci, } \\
\text { 2019) }\end{array}$ & Türkiye & $\begin{array}{l}\text { UFRS'ye geçiş sonrasında } \\
\text { muhasebe verilerinin değer } \\
\text { ilişkisi incelenmektedir. 1999- } \\
2016 \text { y1lları arasında borsada } \\
\text { işlem gören ve imalat } \\
\text { sektöründe faaliyet gösteren } \\
\text { işletmelerin ( } \mathrm{n}=40 \text { ) verisi } \\
\text { üzerinden. }\end{array}$ & $\begin{array}{l}\text { Bulgulara göre işletmelerin öz kaynak } \\
\text { defter değeri ile piyasa değeri arasındaki } \\
\text { ilişki UFRS sonrasında artmıştır. }\end{array}$ \\
\hline (Moura ve & Arjantin, & UFRS'ye zorunlu geçişin & Bulgulara göre UFRS'nin zorunlu geçiş ve \\
\hline
\end{tabular}




\begin{tabular}{|c|c|c|c|}
\hline Gupta, 2019) & $\begin{array}{l}\text { Brezilya, Şili, } \\
\text { Meksika, Peru }\end{array}$ & $\begin{array}{l}\text { analistlerin bilgi ortamını } \\
\text { iyileştirip iyileştirmediğini ve } \\
\text { UFRS'den sonra kamu, özel ve } \\
\text { mutabakat bilgilerinin } \\
\text { doğruluğunun iyileşip } \\
\text { iyileşmediği incelenmektedir. } \\
\text { 2003-2015 yılları arasında } \\
\text { Latin Amerika ülkelerinden } \\
\text { işletme (n=97) verileri. I/B/E/S } \\
\text { ve Datastream üzerinden. }\end{array}$ & $\begin{array}{l}\text { firma düzeyinde raporlama teşvikleri } \\
\text { analistlerin bilgi ortamını iyileştirmiştir. } \\
\text { Kamuoyu ve mutabakat bilgisinin } \\
\text { doğruluğu artırılmış olduğu için UFRS'nin } \\
\text { olumlu etkilerinden söz etmek } \\
\text { mümkündür. }\end{array}$ \\
\hline $\begin{array}{l}\text { (Castro ve } \\
\text { Santana, 2018) }\end{array}$ & Brezilya & $\begin{array}{l}\text { UFRS'ye geçişin sermaye } \\
\text { piyasasında fiyat } \\
\text { bilgilendiriciliği (price } \\
\text { informativeness) üzerindeki } \\
\text { etkisi incelenmektedir. 2004- } \\
2013 \text { yilları arasında borsada } \\
\text { işlem gören işletmelerin } \\
\text { (n=458) verisi Economatica ve } \\
\text { Bloomberg üzerinden. }\end{array}$ & $\begin{array}{l}\text { Bulgulara göre UFRS'ye geçiş sonrasında } \\
\text { firma özelinde bilginin kalitesinin } \\
\text { artmıştır ve hisse senedi fiyatlarının } \\
\text { hareketlerinde piyasadan ziyade firmanın } \\
\text { kendisinden kaynaklı etkinin arttığı tespit } \\
\text { edilmiştir. }\end{array}$ \\
\hline $\begin{array}{l}\text { (Key ve Kim, } \\
2020 \text { ) }\end{array}$ & Güney Kore & $\begin{array}{l}2011 \text { yılında UFRS'ye geçiş } \\
\text { sonrasında muhasebe } \\
\text { kalitesinde artış olup olmadığ1 } \\
\text { incelenmektedir.2006-2015 } \\
\text { yılları arasında işletme } \\
\text { (n=439) verisi. KIS VALUE } \\
\text { üzerinden. }\end{array}$ & $\begin{array}{l}\text { Bulgulara göre UFRS'ye geçişten sonra } \\
\text { muhasebe kalitesinde artış tespit } \\
\text { edilmiştir. Ayrıca UFRS'nin Kore sermaye } \\
\text { piyasasına ve muhasebe sistemine pozitif } \\
\text { etki yaptığı belirtilmiştir. }\end{array}$ \\
\hline $\begin{array}{l}\text { (DeFond vd., } \\
\text { 2019) }\end{array}$ & Çin & $\begin{array}{l}\text { UFRS'ye geçişin etkinliği } \\
\text { finansal tablo kullanıcıları ve } \\
\text { yabancı kurumsal yatırımcılar } \\
\text { açısından incelenmektedir. } \\
\text { 2005-2008 yılları arasında } \\
\text { işletme verileri ( } 5518 \text { firma } \\
\text { y1lı gözlemi). }\end{array}$ & $\begin{array}{l}\text { Bulgulara göre, UFRS'ye geçiş sonrasında } \\
\text { yabancı kurumsal yatırımlar artmazken } \\
\text { tam aksine UFRS'yi başarılı biçimde } \\
\text { uygulayabilecek teşviği olmayan } \\
\text { işletmeler ve/veya gerçeğe uygun değeri } \\
\text { manipüle edebilecek büyüklükte olan } \\
\text { işletmeler için azalmıştır. }\end{array}$ \\
\hline $\begin{array}{l}\text { (Köse vd., } \\
\text { 2020) }\end{array}$ & $\begin{array}{l}\text { Türkiye, } \\
\text { Almanya, } \\
\text { Avusturya, } \\
\text { Belçika, } \\
\text { Danimarka, } \\
\text { Fransa, } \\
\text { İngiltere, } \\
\text { İsveç, İtalya, } \\
\text { Norveç, } \\
\text { Polonya, } \\
\text { Portekiz, } \\
\text { Yunanistan, } \\
\text { ABD, Güney } \\
\text { Kore, Hong } \\
\text { Kong, İsrail, } \\
\text { Japonya, } \\
\text { Kanada, } \\
\text { Singapur, } \\
\text { Yeni Zelanda, } \\
\text { Arjantin, } \\
\text { Brezilya, } \\
\text { Filipinler, } \\
\text { Güney Afrika, }\end{array}$ & $\begin{array}{l}\text { UFRS'ye geçiş sonrasında } \\
\text { ihtiyari (isteğe bağlı) } \\
\text { tahakkukları üzerinden } \\
\text { muhasebe kalitesinin artıp } \\
\text { artmadığı incelenmektedir. }\end{array}$ & $\begin{array}{l}\text { UFRS'ye gönüllü ve zorunlu geçiş göz } \\
\text { önünde bulundurularak elde edilen } \\
\text { bulgulara göre UFRS'ye geçiş genel } \\
\text { olarak muhasebe kalitesinin pozitif yönde } \\
\text { etkilemiştir. Muhasebe kalitesinde artış } \\
\text { ülkeden ülkeye farklılık göstermektedir. } \\
\text { Bazı ülkelerde muhasebe kalitesinde } \\
\text { değişim tespit edilememiştir. }\end{array}$ \\
\hline
\end{tabular}




\begin{tabular}{|c|c|c|c|}
\hline & Şili & & \\
\hline $\begin{array}{l}\text { (Cameran vd., } \\
\text { 2014) }\end{array}$ & İtalya & $\begin{array}{l}\text { UFRS uygulayan halka açık } \\
\text { olmayan işletmelerle domestik } \\
\text { GAAP kullanan işletmelerin } \\
\text { finansal raporlama kalitesi } \\
\text { karşılaştırılması ele } \\
\text { alınmaktadır. 2005-2008 yılları } \\
\text { arasında UFRS uygulayan ve } \\
\text { uygulamayan işletme (n=270) } \\
\text { verisi. }\end{array}$ & $\begin{array}{l}\text { Bulgulara göre UFRS işletmelerinde } \\
\text { finansal raporlama kalitesini artırmamış } \\
\text { tam aksine azaltmıştır. }\end{array}$ \\
\hline $\begin{array}{l}\text { (Ahmed vd., } \\
\text { 2013) }\end{array}$ & - & $\begin{array}{l}\text { UFRS'ye geçişin sonuçları } \\
\text { üzerine Meta-analiz. }\end{array}$ & $\begin{array}{l}\text { Öz kaynak defter değerinin değer } \\
\text { ilişkisinin UFRS sonrasında artmadığı } \\
\text { buna karşın kazançların değer ilişkisi } \\
\text { genel olarak arttığını tespit etmişlerdir. } \\
\text { Ayrıca araştırmada ihtiyari (isteğe bağlı) } \\
\text { tahakkukların UFRS sonrasında } \\
\text { azalmadığı ancak tahmin analistlerin } \\
\text { tahmin doğruluğunun UFRS sonrasında } \\
\text { büyük ölçüde arttığı bulgulanmıştır. }\end{array}$ \\
\hline
\end{tabular}

Tablo 2 incelendiğinde UFRS'ye ilişkin geçiş araştırmalarında zorunlu ve gönüllü geçiş, muhasebe ve finansal raporlama kalitesi, değer ilişkisi, karşılaştırılabilirlik, UFRS'nin çeşitli faydaları, kazanç yönetimi, sermaye yatırımları, kazanç kalitesi, verimlilik gibi konular üzerinde durulduğu görülmektedir. UFRS'ye ilişkin öncesi-sonrası araştırmalarında elde edilen bulgular ülkelere göre farklılık göstermektedir.

UFRS'nin Avrupa Birliği'nde (Li, 2010) sermaye maliyetini düşürdüğü, raporlama kalitesini (Daske ve Gebhardt, 2006) ve muhasebe kalitesini (Chen vd., 2010) arttırdı ğ1 bulgulanmıştır. Öte yandan UFRS'nin muhasebe kalitesini Almanya (Lin, Riccardi ve Wang, 2012) ve İtalya'da (Cameran vd., 2014) düşürdüğü; Güney Afrika (Sellami ve Slimi, 2016) ve Güney Kore'de (Keya ve Kim, 2020) artırdığı yönünde bulguların yanı sıra Endonezya'daki etkisinin ise belirsiz (Fuad vd., 2019) olduğu bulgulanmıştır.

UFRS'nin değer ilişkisini, Birleşik Krallık (Shah vd., 2013) ve Yunanistan'da (Tsalavoutas vd., 2012; Kousenidis vd., 2010) düşürdüğü; Avusturya (Chalmers vd., 2011) ve Türkiye'de (Oral ve Bekci, 2019) artırdığı bulgulanmıştır. Benzer şekilde UFRS'nin çeşitli araştırmalarda raporlama kalitesini (Mikova, 2014; Dayanandan vd., 2016; Kim vd., 2012; Nechita, 2018) muhasebe kalitesini (Ahmed vd., 2013; Trimble, 2018) ve kazanç kalitesini (Alhadi vd., 2018) artırdığ1; sermaye maliyetini (Mihai vd., 2012) düşürdüğü yönünde bulgular vardir.

UFRS'nin etki ve sonuçlarının ele alındığı araştırmalarda elde edilen bulgular UFRS'nin ülke, bölge ve hatta işletme özelinde farklı sonuçlar verdiğini göstermektedir. Hatta araştırmalarda UFRS'nin aynı değişkenler için farklı sonuçlar verdiği bulgulara da rastlanmaktadır. Örneğin, UFRS kazanç yönetimi uygulamaları üzerinde Türkiye'de (Zor ve Korga, 2020) olumlu etki yaparken; Avustralya, Fransa, Birleşik Krallık'ta (Jeanjean ve Stolowy, 2008) olumsuz etki yapmaktadır. Bu durum standartların farklı ülkelerde, farklı yönetsel ve örgütsel dinamiklere sahip işletmelerde aynı sonuçları verebildiğini göstermektedir. Jeanjean ve Stolowy (2008) araştırmalarında standartların işletmeler arasında ortak bir iş dili oluşturmak için yeterli olmadığı; yönetim teşviklerinin ve ulusal kurumsal 
faktörlerin finansal raporlama özelliklerinin çerçevelenmesinde önemli bir rol oynadığını vurgulamaktadır.

Genel olarak UFRS, yatırımcı korumasının düşük olduğu ülkelerde UFRS bilgi kalitesini artırmıştır (Houqe vd., 2014). Ülkedeki kültür, muhasebe sistemi, hukuki yap1, yatırımcıyı korumaya yönelik düzenlemeler UFRS'den elde edilen sonuçlarda etkili olmaktadır (Karampinis ve Hevas, 2011). UFRS karşılaştırılabilirlik anlamında önemli katkılar sağlarken; UFRS kurucularının (IASB, 2018) UFRS'nin sağlayacağı faydaların her ülke için aynı düzeyde gerçekleştiği yönünde belirsizlikler bulunmaktadır. Ortaya çıkan tablo sonucunda, UFRS'nin görece düşük kalitede yerel muhasebe standartlarına sahip ülkelerde, görece yüksek kalitede yerel muhasebe standartlarına sahip ülkelere göre daha iyi sonuçlar verdiğini ifade etmek yanlış olmayacaktır.

\subsection{UFRS’nin İşletmelerde Yol Açtığı Güçlükler Ve Ekonomik Sonuçları}

UFRS'ye geçiş sürecinde ve geçiş sonrasında işletmelerin, üst yöneticilerin, çalışanların, muhasebe ve iç denetim biriminin karşılaştığı güçlükler, UFRS'nin denetim ücretlerinde ve denetim dişı ücretlerde yol açtı̆̆ gerçekleştirilen araştırmalara Tablo 3 'te yer verilmektedir.

Tablo 3. UFRS’nin İşletmelerde Yol Açtığı Güçlükler ve Ekonomik Sonuçları

\begin{tabular}{|c|c|c|c|}
\hline Araştırma(lar) & Ülke(ler) & $\begin{array}{l}\text { Araştırma Kapsamı ve } \\
\text { Kullanılan Veri }\end{array}$ & Araştırma Bulguları ve Sonuçları \\
\hline (Griffin vd., 2009) & Yeni Zelanda & $\begin{array}{l}\text { Denetim ücretleri, } \\
\text { denetim dış1 ücretlerin } \\
\text { UFRS'ye geçiş ile } \\
\text { gösterdiği değişim. } \\
\text { 2002-2007 yılları } \\
\text { arasında (653 firma yılı } \\
\text { gözlemi) firma verisi. } \\
\text { OSIRIS üzerinden veri. }\end{array}$ & $\begin{array}{l}\text { 2002-2006 yılları arasında UFRS'ye } \\
\text { geçişle birlikte denetim ücretleri } \\
\text { (özellikle Big Four) önemli ölçüde } \\
\text { artmıştır. }\end{array}$ \\
\hline $\begin{array}{l}\text { (Navarro-García ve } \\
\text { Bastida, 2010) }\end{array}$ & İspanya & $\begin{array}{l}\text { UFRS'ye geçişin } \\
\text { sonuçlarının analiz } \\
\text { edilmesi. Halka açık } \\
\text { işletmelerden }(\mathrm{n}=63) \\
\text { anket verisi. }\end{array}$ & $\begin{array}{l}\text { Elde edilen verilere göre Finans ve } \\
\text { Muhasebe yöneticileri UFRS'yi karar } \\
\text { verme süreçleri için yüksek standartlara } \\
\text { sahip bir düzenleme olarak görmektedir. } \\
\text { Ancak aynı zamanda katılımcılar } \\
\text { UFRS'yi yerel muhasebe } \\
\text { standartlarından önemli ölçüde farklı, } \\
\text { zahmetli ve bazı durumlarda } \\
\text { fayda/maliyet dengesini karşılamada } \\
\text { başarısız olarak görmektedirler. Ayrıca } \\
\text { katılımcılar UFRS'nin yerel muhasebe } \\
\text { standartlarından daha kabul edilebilir } \\
\text { olduğunu da düsünmemektedir. }\end{array}$ \\
\hline (Pawsey, 2017) & Avustralya & $\begin{array}{l}\text { UFRS'ye geçiş ve } \\
\text { UFRS altında } \\
\text { faaliyetlerin } \\
\text { gerçekleştirilmesinin } \\
\text { maliyeti. Çeşitli } \\
\text { sektörlerde faaliyet } \\
\text { gösteren işletmelerden } \\
\text { anket verisi (n=166, } \\
\end{array}$ & $\begin{array}{l}\text { UFRS'ye geçiş, muhasebe bilgi sistemi, } \\
\text { personel eğitimi ve geliştirme, finansal } \\
\text { tablo kullanıcı eğitimi ve finansal } \\
\text { tabloların düzenlenmesinde maliyetlere } \\
\text { neden olmuştur. Pek çok işletme } \\
\text { UFRS'ye geçişin devam eden süreçte } \\
\text { yıllık \%20 ve üzerinde muhasebe ve } \\
\text { uyum maliyetlerine yol açacağını }\end{array}$ \\
\hline
\end{tabular}




\begin{tabular}{|c|c|c|c|}
\hline & & $\mathrm{N}=801)$ & belirtmektedir. \\
\hline $\begin{array}{l}\text { (Vieru ve } \\
\text { Schadewitz, 2010) }\end{array}$ & Finlandiya & $\begin{array}{l}\text { UFRS’nin denetim ve } \\
\text { denetim diş1 ücretler } \\
\text { üzerinde etkisi. 2004- } \\
2005 \text { y1lları halka açık } \\
\text { işletme (n=73) verisi } \\
\text { üzerinden. }\end{array}$ & $\begin{array}{l}\text { UFRS ile denetim ve denetim dış1 } \\
\text { ücretleri pozitif yönde önemli düzeyde } \\
\text { etkilemiştir. }\end{array}$ \\
\hline (George vd., 2013) & Avustralya & $\begin{array}{l}\text { Halka açık işletmelerin } \\
\text { UFRS'ye geçişinin } \\
\text { denetim ücretlerinde yol } \\
\text { açtığı artış. 2002-2006 } \\
\text { y1lları arasında } 907 \\
\text { halka açık işletmenin } \\
\text { (4.535 firma yılı } \\
\text { gözlemi) finansal } \\
\text { raporları üzerinden elde } \\
\text { edilen veriler. }\end{array}$ & $\begin{array}{l}\text { UFRS'ye geçiş yapıldığı yılda denetim } \\
\text { ücretlerinde \%23'lük bir artış } \\
\text { gözlemlenmiştir. Bu artı̧ın \%8'i } \\
\text { doğrudan UFRS ile ilgili olduğu tahmin } \\
\text { edilmektedir. }\end{array}$ \\
\hline (Kim vd., 2012) & $\begin{array}{l}\text { Avusturya, } \\
\text { Belçika, } \\
\text { Danimarka, } \\
\text { Finlandiya, } \\
\text { Fransa, Almanya, } \\
\text { Yunanistan, } \\
\text { İrlanda, İtalya, } \\
\text { Hollanda, } \\
\text { Portekiz, İspanya, } \\
\text { İsveç, Birleşik } \\
\text { Krallık }\end{array}$ & $\begin{array}{l}\text { UFRS'ye geçişin } \\
\text { denetim ücretleri } \\
\text { üzerine etkisi. 2004- } \\
2008 \text { yılları arasında } 11 \\
\text { Avrupa birliği } \\
\text { ülkesindeki (3.693 } \\
\text { firma yılı gözlemi) } \\
\text { işletme verisi. } \\
\text { Worldscope üzerinden. }\end{array}$ & $\begin{array}{l}\text { UFRS'nin getirmiş olduğu kompleks } \\
\text { yapı nedeniyle denetim ücretleri önemli } \\
\text { ölçüde artmıştır. }\end{array}$ \\
\hline (Morris vd., 2014) & Avustralya & $\begin{array}{l}2006 \text { yılında borsada } \\
\text { işlem gören işletmelerin } \\
(\mathrm{n}=305) \text { UFRS'ye geçiş } \\
\text { sonrasında } \\
\text { karşılaştıkları zorluklar, } \\
\text { maliyet ve elde ettikleri } \\
\text { faydanın ölçülmesi. }\end{array}$ & $\begin{array}{l}\text { Bulgulara göre katılımcıların en az } \\
\% 40 \text { 'ı karşılaştıkları güçlüklerin } \\
\text { standartların getirmiş olduğu kompleks } \\
\text { yapı, belirsizlik, teknik bilgi gereğinden } \\
\text { ve personel sorunlarından (UFRS } \\
\text { üzerine harcanan zaman) } \\
\text { kaynaklandığını belirtmişlerdir. UFRS } \\
\text { ile birlikte ortaya çıan bir defaya } \\
\text { mahsus ve devam eden maliyetlerin ise } \\
500.000 \$ \text { dolara ulaşabileceği ve } \\
\text { gelecekte UFRS altında finansal } \\
\text { raporları hazırlamanın ilave maliyetlere } \\
\text { yol açarak UFRS'nin işletmeler } \\
\text { üzerindeki maliyet yükünü artıracağını } \\
\text { ifade etmişlerdir. }\end{array}$ \\
\hline (Taylor, 2009) & $\begin{array}{l}\text { Birleşik Krallık, } \\
\text { Hong Kong, } \\
\text { Singapur }\end{array}$ & $\begin{array}{l}\text { Finansal tablo } \\
\text { hazırlayıcılarına } \\
\text { UFRS'ye geçişin } \\
\text { maliyeti ve UFRS'nin } \\
\text { getirdiği faydanın } \\
\text { incelenmesi. UFRS'ye } \\
\text { geçiş aşamaları } \\
\text { birbirinden farklı olan } \\
\text { üç ülkede faaliyet } \\
\text { gösteren işletmenin } \\
\text { (n=150) verisi } \\
\text { üzerinden. }\end{array}$ & $\begin{array}{l}\text { Bulgulara göre Birleşik Krallık'ta } \\
\text { UFRS'ye ilk geçişte gerçekleştirilecek } \\
\text { düzenlemelerin boyutu ve maliyeti, } \\
\text { Hong Kong ve Singapur'daki } \\
\text { işletmelere kıyasla daha fazladır. Ancak, } \\
\text { üç ülkenin her birinde, UFRS altında } \\
\text { hazırlanan mali tablolar, yerel genel } \\
\text { kabul görmüs raporlama uygulamaları } \\
\text { kapsamında hazırlanan mali tablolara } \\
\text { göre daha fazla değerle alakalı bilgi } \\
\text { sağlama açısından kullanıcılara önemsiz } \\
\text { faydalar sağlamaktadır. Birleşik } \\
\text { Krallık'ın UFRS'ye geçiş stratejisi, }\end{array}$ \\
\hline
\end{tabular}




\begin{tabular}{|c|c|c|c|}
\hline & & & $\begin{array}{l}\text { Hong Kong ve Singapur'dan daha } \\
\text { yüksek fayda maliyetlerine maruz } \\
\text { kalmasına neden olmuştur. }\end{array}$ \\
\hline $\begin{array}{l}\text { (Cameran ve Perotti, } \\
\text { 2014) }\end{array}$ & İtalya & $\begin{array}{l}\text { UFRS'nin denetim } \\
\text { ücretleri üzerine etkisi } \\
\text { incelenmektedir. 1999- } \\
2006 \text { yılları arasında } \\
\text { bankacılık sektöründe } \\
\text { (n=136) anket } \\
\text { uygulaması ve finansal } \\
\text { veriler üzerinden. }\end{array}$ & $\begin{array}{l}\text { Bulgulara göre UFRS'ye geçişten sonra } \\
\text { denetim ücretleri \%19.29 oranında } \\
\text { artmıştır. Ayrıca UFRS sonrasında } \\
\text { finansal raporlama kalitesinde artış } \\
\text { olduğuna dair bulgu tespit } \\
\text { edilememiştir. Denetim ücretlerindeki } \\
\text { artış UFRS'nin yol açtığı iş yükünden } \\
\text { kaynaklandığı ifade edilmektedir. }\end{array}$ \\
\hline
\end{tabular}

Tablo 3’te yer alan bulgulara göre, UFRS denetim (Griffin vd., 2009; Kim vd., 2012) ve denetim dışı (Vieru ve Schadewitz, 2010) ücretlerde artışa neden olmuştur. Özellikle geçişin yapıldığı yılda \%23'lük artışın \%8'inin doğrudan UFRS ile ilgili olduğu tahmin edilmektedir (Vieru ve Schadewitz, 2010).

UFRS'ye geçiş, muhasebe bilgi sistemi, personel eğitimi ve geliştirme, finansal tablo kullanıcı eğitimi ve finansal tabloların düzenlenmesinde ek maliyetlere neden olmuştur (Pawsey, 2017; Morris vd., 2014). Bu maliyet artışlarına kıyasla UFRS'nin getirisi göz önünde bulundurulduğunda işletmeler açısından olumsuz bir tablo ortaya çıkmaktadır. Başka bir ifadeyle UFRS'ye geçiş fayda/maliyet dengesi açısından işletmenin aleyhine sonuçlar verdiği araştırmalar bulunmaktadır (Taylor, 2009; Cameran ve Perotti, 2014; Navarro-García ve Bastida, 2010).

\section{SONUÇ}

Muhasebe tarihindeki önemli gelişmelerden birisi olan UFRS, 1 Ocak 2005'te Avrupa Birliği'nde zorunlu olarak uygulanmaya başlamış, 1 Ocak 2021 tarihi itibariyle 16 yılı geride bırakmıştır. Zorunlu uygulama başladıktan sonra dünya genelinde ilgi görmeye başlamış ve zorunlu-gönüllü geçişlerle birlikte 2018 yılında 144 ülkede kullanılır hale gelmiştir. UFRS'ye yönelik artan ilgi UFRS'nin faydaları-sakıncaları tartışmalarını da beraberinde getirmiş ve çeşitli ülkelerde UFRS üzerine araştırmalar gerçekleştirilmiştir.

Söz konusu bu araştırmalar incelendiğinde, UFRS öncesinde UFRS'ye yönelik algının tespit edildiği araştırmalardaki maliyet, güçlükler, denetim firmalarına bağımlılık gibi öngörülerin büyük ölçüde gerçekleştiğini söylemek mümkündür. UFRS'ye zorunlu geçişin ilk dönemlerinde kalifiye personel eksikliği ve uygulama rehberinin olmayışı UFRS kullanıcılarının denetim firmalarına bağımlılıklarını artırmıştır. Bu durum ise başta Big Four olmak üzere denetim firmalarının ücretlerinde artışa neden olmuştur. Denetim ücretlerindeki artışın yanı sıra denetim dışı ücretlerde de ek maliyetlere yol açan UFRS'nin gelecekte de işletmelere ek maliyetler getireceği düşünülmektedir.

Araştırmalarda işletmelerin UFRS'ye geçişte karşılaştığ 1 güçlükler, geçiş ve gelecekte ortaya çıkacak maliyetler ile UFRS'nin getirisi kıyaslandığında fiyat/maliyet dengesinin işletme aleyhine ve/veya lehine olduğunu gösteren farklı bulgulara rastlanmaktadır. Ancak bu araştırmalarda işletme aleyhine olduğu bulguları daha fazladır. Başka bir ifadeyle bazı ülkelerde gerçekleştirilen araştırmalarda elde edilen bulgulara göre UFRS'nin kompleks yapısı nedeniyle işletmelere getirdiği iş yükü ve yol açtı̆̆ 1 maliyetlere kıyasla işletmelere katkısı düşük düzeyde kalmıştır. 
Araştırmalardaki bir diğer bulgu, UFRS'nin ülkeden ülkeye farklı sonuçlar verdiğidir. Çünkü ülkedeki kültür, muhasebe sistemi, hukuki yapı, yatırımcıyı korumaya yönelik düzenlemeler UFRS'den elde edilen sonuçlarda etkili olmaktadır. Örneğin bazı ülkelerde UFRS sonrasında karşılaştırılabilirlik, muhasebe ve finansal raporlama kalitesi ve değer ilişkisinde artış olduğunu gösteren bulgular elde edilirken bazı ülkelerde tam tersi sonuçlar elde edildiği belirtilmektedir. Hatta bazı ülkelerde UFRS'nin getirisi belirsizdir. Ayrıca UFRS'ye zorunlu veya gönüllü geçiş biçimleriyle de elde edilen sonuçların farklılaştığını gösteren bulgular da vardır.

UFRS'ye geçişte, muhasebe bilgi sistemine önceden yatırımlar yapmış, iç kontrol ve iç denetim bileşenlerini oluşturmuş olan büyük ölçekli işletmelerin küçük ölçekli işletmelere göre daha avantajlı olduğu araştırmalarda elde edilen bir diğer bulgudur. UFRS'nin özellikle ilk yıllarında nasıl uygulanacağı noktasında yaşanan zorluklarla mücadele noktasında büyük ölçekli işletmeler kalifiye personel ve bilgiye erişim noktasında avantajlı durumdayken işlem hacmi ve iş yükünde dezavantajlı durumda olduğu tespit edilmiştir.

2018 yılında 144 ülkeye ulaşan UFRS uygulaması ile işletmelerde ortak bir raporlama dilinin oluşturulması çabaları giderek yaygınlaşmıştır. UFRS'ye getirilebilecek eleştirilerin başında tek tipleşmenin gelecekte daha yüksek muhasebe ve finansal raporlama kalitesi sağlayabilecek uygulamaların (standartların) önüne set çekmesidir. Çünkü UFRS zorunlu ve/veya gönüllü geçiş ile uluslararası raporlama dilini tek tipleştirmekte ve alternatiflerini ortadan kaldırmaktadır. Örneğin bir ülkede belirlenmiş yerel raporlama standartları muhasebe ve finansal raporlama kalitesi noktasında daha iyi sonuçlar verebilir ve bu yerel standartlar belirli bir süre sonra yaygınlaşabilir. UFRS ile bu durum ihtimal dâhilinden çıkmaktadır.

Araştırmalarda UFRS'ye getirilen bir diğer eleştiri zorunlu geçiş ile ilgilidir. Örneğin Atwood vd. (2011) tarafindan gerçekleştirilen ve 33 ülkeyi kapsayan araştırmada elde edilen bulgulara göre UFRS, US GAAP ve yerel DAS kıyaslamasında UFRS'nin diğerlerinden farklı sonuçlar vermediği hatta US GAAP ile hazırlanan finansal tabloların değer ilişkisi UFRS'ye göre daha yüksektir. Benzer şekilde Lin vd., (2012) tarafından Almanya'da gerçekleştirilen araştırmada US GAAP'ın UFRS'ye göre daha yüksek muhasebe kalitesi sağladığı; UFRS'ye geçişin muhasebe kalitesini düşürdüğü bulgulanmıştır.

UFRS, karşılaştırılabilirliğin artırılmasında önemli katkılar sağlamıştır. Yatırımcı korumasına ilişkin düzenlemelerin kısıtlı olduğu ülkelerde UFRS daha iyi sonuçlar verirken hâlihazırda yüksek kalitede muhasebe ve finansal raporlamasına sahip ülkelerde etkisi sınırlı kalmış ve hatta bazı ülkelerde kayıplara neden olmuştur. Başka bir ifadeyle UFRS uygulamasına geçen bir ülkede yürürlükte olan yerel muhasebe standartlarının UFRS standartlarından daha düşük kalitede olması durumunda UFRS'nin katkı sağladığını; tersi durumda ise UFRS'nin katkısının belirsiz olduğunu söylemek mümkündür.

Gelecekte yapılacak çalışmalarda ülke odaklı araştırmalar gerçekleştirilerek UFRS'nin faydaları-sakıncaları konusunda literatüre katkılar sağlanabilir. Benzer şekilde UFRS'nin başta denetim maliyetleri olmak üzere yol açtığı ekonomik sonuçlar üzerine araştırmalar gerçekleş̧irilebilir. Ayrıca işletmeler, muhasebeciler, denetim şirketleri, yatırımcılar gibi UFRS paydaşları ile nitel araştırmalar gerçekleştirilerek UFRS öncesinde algının ölçüldüğü araştırmalar gibi UFRS sonrasındaki güncel durum tespit edilebilir. 
$\mathrm{Bu}$ çalışmada yer verilen UFRS'ye yönelik araştırma bulguları üzerinden gerçekleştirilen yorumlar UFRS'nin faydaları-sakıncaları konusunda genelleme yapılamaz. UFRS'ye gönüllü veya zorunlu geçiş ve ülkelerin farklı tarihlerde UFRS'ye geçmiş olmaları nedeniyle UFRS'den elde edilen fayda/sakınca gelecekte farklılık gösterebilir. Bazı ülkeler 2005 yılında UFRS'ye geçiş yapmışken bazı ülkeler 2018 yılında geçmiştir. Dolayısıyla araştırmalarda elde edilen bulgular kullanılan veri setleri ile sınırılığının etkisi altındadır.

\section{KAYNAKLAR}

Ahmed, Anwer - Neel, Michael - Wang, Dechun (2013), "Does mandatory adoption of IFRS improve accounting quality? Preliminary evidence", Contemporary Accounting Research, 30(4), pp.1344-1372.

Ahmed, Kamran - Chalmers, Keryn - Khlif, Hichem (2013), "A Meta-analysis of IFRS Adoption Effects", The International Journal of Accounting, 48, pp.173-217.

Alhadi, Salah, Abd - Senik, Rosmila - Johari, Jalila (2018), "Institutional Ownership and Earnings Quality pre- and post-IFRS", Int. Journal of Economics and Management, 12(2), pp.747-757.

Atwood, TJ - Drake, Michael - Myers, James, - Myers, Linda (2011), "Do earnings reported under IFRS tell us more about future earnings and cash flows", Journal of Accounting and Public Policy, 30(2), pp.103-121.

Beneish, Messod - Miller, Brain - Yohn, Teri Lombardi (2015), "Macroeconomic evidence on the impact of mandatory IFRS adoption on equity and debt markets", Journal of Accounting and Public Policy, 34(1), pp.1-27.

Cameran, Mara - Perotti, Pietro (2014), "Audit Fees and IAS/IFRS Adoption: Evidence from the Banking Industry", International Journal of Auditing, 18, pp.155-169.

Cameran, Mara - Campa, Domenico - Pettinicchio, Angela (2014), "IFRS Adoption Among Private Companies: Impact on Earnings Quality", Journal of Accounting, Auditing \& Finance, 29(3), pp.278-305.

Castro, Henrique - Santana, Veronica (2018), "Informativeness of stock prices after IFRS adoption in Brazil", Journal of Multinational Financial Management, 47(48), pp.46-59.

Chalmers, Keryn - Clinch, Greg - Godfrey, Jayne (2011), "Changes in value relevance of accounting information upon IFRS adoption: Evidence from Australia", Australian Journal of Management, 36(2), pp.151-173.

Chen, Huifa - Tang, Qingliang - Jiang, Yihong - Lin, Zhijun (2010), "The Role of International Financial Reporting Standards in Accounting Quality: Evidence from the European Union", Journal of International Financial Management and Accounting, 21(3), pp.220-278 
Clements, Curtis - Neill, John D - Stovall, O. Scott (2010), "Cultural Diversity, Country Size, And The IFRS Adoption Decision", The Journal of Applied Business Research, 26(2), pp.115-126.

Daske, Holger - Gebhardt, Günther (2006), "International Financial Reporting Standards and Experts’ Perceptions of Disclosure Quality", Abacus, 42(3/4), pp.461-498

Daske, Holger - Hail, Luzi - Leuz, Christian - Verdi, Rodrigo (2008), "Mandatory IFRS Reporting around the World: Early Evidence", Journal of Accounting Research, 46(5), pp.1085-1142.

Dayanandan, Ajit - Donker, Han - Ivanof, Mike - Karahan, Gökhan (2016), "IFRS and accounting quality: legal origin, regional, and disclosure impacts", International Journal of Accounting and Information Management, 24(3), pp.296-316.

DeFond, Mark - Gao, Xinzi - Li, Oliver Zhen - Xia, Lijun (2019), "IFRS adoption in China and foreign institutional investments", China Journal of Accounting Research, 12, pp.1-32.

Doan, Dung Thi - Nguyen, Lan Ngoc Thi, - Phan, Hai Thanh (2020), "Factors affecting the application of IFRS through the perceptions of business managers and auditors in Vietnam", Problems and Perspectives in Management, 18(1), pp.371-384.

Downes, Jimmy F. - Flagmeier, Vanessa - Godsell, David (2018), "Product market effects of IFRS adoption", Journal of Accounting and Public Policy, 37(5), pp.376-401.

Erin, Olayinka - Olojede, Paul - Ogundele, Olaoye (2017), "Value Relevance of Accounting Data in the Pre and Post IFRS Era: Evidence from Nigeria", International Journal of Finance and Accounting, 6(4), pp.95-103.

Fuad, Fuad - Juliarto, Agung - Harto, Puji (2019), "Does IFRS convergence really increase accounting qualities? Emerging market evidence", Journal of Economics, Finance and Administrative Science, 24(48), pp.205-220.

George, Emmanuel - Ferguson, Colin - Spear, Nasser (2013), "How Much Does IFRS Cost? IFRS Adoption and Audit Fees", American Accounting Association, 88(2), pp.429462.

Griffin, Paul - Lont, David H - Sun, Yuan (2009), "Governance regulatory changes, International Financial Reporting Standards adoption, and New Zealand audit and non-audit fees: empirical evidence", Accounting and Finance, 49, pp.697-724.

Houqe, Muhammad Nurul - Easton, Samuel - Zijl, Tony van (2014), "Does mandatory IFRS adoption improve information quality in low investor protection countries?", Journal of International Accounting, Auditing and Taxation, 23, pp.87-97.

Humeedat, Mohammad (2019), "Changes in Accounting Conservatism in Pre- and Post- IFRS Adoption in Jordan", Research Journal of Finance and Accounting, 10(4), pp.9-14. 
International Accounting Standards Board (2020), Use of IFRS Standards around the world. https://cdn.ifrs.org/-/media/feature/around-the-world/adoption/use-of-ifrs-around-theworld-overview-sept-2018.pdf Erişim tarihi: 30.10.2020

Jeanjean, Thomas - Stolowy, Herve (2008), "Do accounting standards matter? An exploratory analysis of earnings management before and after IFRS adoption", Journal of Accounting and Public Policy, 27, pp.480-494.

Jermakowicz, Eva (2004), "Effects of Adoption of International Financial Reporting Standards in Belgium: The Evidence from BEL-20 Companies", Accounting in Europe, 1(1), pp.51-70.

Jermakowicz, Eva - Gornik-Tomaszewski, Sylwia (2006), "Implementing IFRS from the perspective of EU publicly traded companies", Journal of International Accounting, Auditing and Taxation, 15(2), pp.170-196.

Jones, Stewart - Finley, Aimee (2011), "Have IFRS made a difference to intra-country financial reporting diversity?", The British Accounting Review, 43, pp.22-38.

Jones, Stewart - Higgins, Alison (2006), "Australia's switch to international financial reporting standards: a perspective from account preparers", Accounting and Finance, 46, pp.629-652.

Karampinis, Nikolaos - Hevas, Dimosthenis (2011), "Mandating IFRS in an Unfavorable Environment: The Greek Experience", International Journal of Accounting, 46(3), pp.304-332.

Kaya, Ahmet - Hatunoğlu, Zeynep - Özçalıcı, Mehmet (2015), "Türkiye’deki Tekstil Firmalarının Verimlilik Değerlerinin TFRS Öncesi ve Sonrası Dönemler için Karşılaştırılması", Uluslararası Alanya İşletme Fakültesi Dergisi, 7(3), ss.79-90.

Kaya, Devrimi - Koch, Maximilian (2015), "Countries’ adoption of the International Financial Reporting Standard for Small and Medium-sized Entities (IFRS for SMEs) - early empirical evidence", Accounting and Business Research, 45(1), pp.93-120.

Key, Kimberly G - Kim, Jeong Youn (2020), "IFRS and accounting quality: Additional evidence from Korea", Journal of International Accounting, Auditing and Taxation, 39, pp.1-12.

Kim, Jeong-Bon - Liu, Xiaohong - Zheng, Liu (2012), "The Impact of Mandatory IFRS Adoption on Audit Fees: Theory and Evidence", American Accounting Association, 87(6), pp.2061-2094.

Kim, Oksana (2016), "The IFRS Adoption Reform through the Lens of Neoinstitutionalism: The Case of the Russian Federation", The International Journal of Accounting, 51(3), pp.345-362. 
Kousenidis, Dimitros V - Ladas, Anestis. C - Negakis, Christos I (2010), "Value Relevance of Accounting Information in the Pre- and Post-IFRS Accounting Periods", European Research Studies, 13(1), pp.145-154.

Köse, Eda - Bekçi, İsmail - Çetenak, Hüseyin Emin (2020), "Finansal Raporlama Standartlarının Muhasebe Kalitesine Etkisi Üzerine Bir Araştırma", Muhasebe ve Vergi Uygulamaları Dergisi, 13(1), ss.1-23.

Li, Siqi (2010), "Does Mandatory Adoption of International Financial Reporting", The Accounting Review, 85(2), pp.607-636.

Lin, Steve - Riccardi, William - Wang, Changjiang (2012), "Does accounting quality change following a switch from U.S. GAAP to IFRS? Evidence from Germany", Journal of Accounting and Public Policy, 31(6), pp.641-657.

Mihai, Stere - Ionascu, Mihaela - Ionascu, Ion (2012), "Economic benefits of International Financial Reporting Standards (IFRS) adoption in Romania: Has the cost of equity capital decreased?", African Journal of Business Management, 6(1), pp.200-205.

Mikova, T (2014), "Pre and Post IFRS Loss Avoidance in France and the United Kingdom", International Journal of Economics and Management Engineering, 8(8), pp.25712578.

Morris, Richard D - Gray, Sidney J - Pickering, Joanne - Aisbitt, Sally (2014), "Preparers' perceptions of the costs and benefits of IFRS: Evidence from Australia's Implementation Experience", Accounting Horizons, 28(1), pp.143-173.

Moscariello, Nicola - Skerratt, Len - Pizzo, Michele (2004), "Mandatory IFRS adoption and the cost of debt in Italy and UK", Accounting and Business Research, 44(1), pp.63-82.

Moura, André Aroldo Freitas de - Gupta, Jairaj (2019), "Mandatory adoption of IFRS in Latin America: A boon or a bias", Journal of International Financial Markets, Institutions \& Money, 60, pp.111-133.

Navarro-García, Juan Carlos - Bastida, Francisco (2010), "An empirical insight on Spanish listed companies' perceptions of International Financial Reporting Standards", Journal of International Accounting, Auditing and Taxation, 19(2), pp.110-120.

Nechita, Elena (2018), "A pre-post IFRS analysis on the quality of financial reporting. Evidence from an emerging economy", Accounting and Management Information Systems, pp.202-216. Budapeşte.

Neel, Michael (2017), "Accounting Comparability and Economic Outcomes of Mandatory IFRS Adoption", Contemporary Accounting Research, 34(1), pp.658-690.

Nurunnabi, Mohammad (2018), "Perceived costs and benefits of IFRS adoption in Saudi Arabia: An exploratory study", Research in Accounting Regulation, 30, pp.166-175. 
Oral, İnci Çisil - Bekci, İsmail (2019), "TFRS’nin Finansal Raporlara Etkisinin Değer İlgisi ile Tespiti: Bist İmalat Sanayi Sektöründe Bir Uygulama", Süleyman Demirel Üniversitesi Vizyoner Dergisi, 10(23), ss.99-107.

Pawsey, Nicholas L (2017), "IFRS adoption: A costly change that keeps on costing", Accounting Forum, 41(2), pp.116-131.

Sellami, Yosra Mnif - Slimi, Imen (2016), "The effect of the mandatory adoption of IAS/IFRS on earnings management: Empirical evidence from South Africa", International Journal of Accounting and Economics Studies, 4(2), pp.87-95.

Shah, Syed Zulfiqar Ali - Liang, Shuang - Akbar, Saeed (2013), "International Financial Reporting Standards and the value relevance of R\&D expenditures: Pre and post IFRS analysis", International Review of Financial Analysis, 30, pp.158-169.

Taylor, Dennis W (2009), "Costs-benefits of adoption of IFRSs in countries with different harmonization histories", Asian Review of Accounting, 17(1), pp.40-58.

Trimble, Madeline (2018), "A Reinvestigation into Accounting Quality Following Global IFRS Adoption: Evidence via Earnings Distributions", Journal of International Accounting, Auditing and Taxation, 33, pp.18-39.

Tsalavoutas, Ioannis - André, Paul - Evans, Lisa (2012), "The transition to IFRS and the value relevance of financial statements in Greece", The British Accounting Review, 44, pp.262-277.

Tyrrall, David - Woodward, David - Rakhimbekova, Almagoul (2007), "The relevance of International Financial Reporting Standards to a developing country: Evidence from Kazakhstan", International Journal of Accounting, 42, pp.82-110.

Ugrin, Joseph C - Mason, Terry W - Emley, Anna (2017), "Culture's consequence: The relationship between income-increasing earnings management and IAS/IFRS adoption across cultures", Advances in Accounting, 37, pp.140-151.

Vieru, Markku - Schadewitz, Hannu (2010), "Impact of IFRS transition on audit and nonaudit fees: evidence from small and medium-sized listed companies in Finland", The Finnish Journal of Business Economics, 59(1), pp.11-41.

Zor, İsrafil - Korga, Selda (2020), "Türkiye Muhasebe ve Finansal Raporlama Standartlarının Kazanç Yönetimi Uygulamalarına Etkisi", Muhasebe ve Finansman Dergisi, 86, ss.124. 
